\title{
Job Insecurity, Job Instability, and Job Satisfaction in the Context of the COVID-19 Pandemic
}

\section{- Marcela-Sefora Nemteanu, Vasile Dinu, Dan-Cristian Dabija}

\begin{abstract}
The COVID-19 pandemic has brought new challenges regarding employee adaptation to change as well as job security, with levels of wellbeing and satisfaction being greatly affected. Based on the literature as well as on Adaptation-level Theory, Stress and Coping Theory, and Motivationhygiene Theory, this paper approaches the link between job insecurity and job instability during the COVID-19 pandemic along with employee job satisfaction in an emerging market. The proposed conceptual model analyses the influence of job instability and job insecurity on individual job satisfaction, including supervisor support and promotion opportunities. The survey-based empirical study was implemented with the aid of a questionnaire taken by 568 employees in Romania. The results determined with the help of a correlation analysis highlight a strong, direct, and positive link between job instability and employee insecurity in increasing employee competitiveness. The impact of job insecurity and instability on the components considered in terms of job satisfaction vary. Job insecurity was shown to manifest a negative correlation only with regard to satisfaction concerning supervisor support and promotion opportunities. Perceived job instability showed a significant negative impact on individual work satisfaction, satisfaction with supervisor support and promotion opportunities. This paper also enhances the human resources literature by demonstrating how organisational competitiveness might be enhanced during a global pandemic by focusing on employees.
\end{abstract}

Keywords: job insecurity, job satisfaction, COVID-19 pandemic, promotion opportunities, emerging market, employees' competitiveness, Romania

JEL Classification: J28, J53, M12, M30, M31, M54

Received: November, 2020

1st Revision: April, 2021

Accepted: April, 2021

\section{INTRODUCTION}

The context of the COVID-19 pandemic has engendered a change in organisational dynamics, with organisations having to considerably decrease activity (Bartik et al., 2020) as well as to reduce jobs or employee working hours. These conditions have generally led to lower productivity and organisational competitiveness (ILO, 2020). Workers in various industrial branches have experienced not only the jeopardization of their workplace but also their prospects for 
employment (Fernandes, 2020). Job insecurity may be due to the particular employee in question, with some simply not able to cope with the stress generated by the job requirements or the high level of control (Strazdins et al., 2004). Job instability and job insecurity are also caused by the turmoil related to the labour market (Böckerman et al., 2011), in which in the struggle to maintain competitiveness economic actors have implemented deep restructuring across the business sector and have often experienced increased competition within the industry (Hassard $\&$ Morris, 2017) and in terms of technological developments and innovation as well as socioeconomic crises and/or sanitary crises (Wilson et al., 2020). The literature highlights findings showing that job instability and job insecurity are associated with low levels of job satisfaction (Reisel et al., 2010). This paper covers several gaps in the literature in terms of assessing the links among job instability, job insecurity, and job satisfaction (general satisfaction, satisfaction with supervisor care, satisfaction concerning promotion opportunities) from an employee competitiveness perspective. The direct link between perceived instability and job insecurity has been previously discussed within academic research (Landsbergis et al., 2012). Still, the empirical links between these two variables have been explored to a lesser degree. Recent approaches in the context of the COVID-19 pandemic regarding job instability and its impact on employees' sense of security have not yet come forth in academic research. This study fills a research gap and highlights a strong, significant, and positive link between job instability and job insecurity based on empirical results.

The purpose of this paper is to identify in the context of the COVID-19 pandemic employee perceptions regarding job insecurity and job instability as well as the effects of these factors on job satisfaction in Romania. From a theoretical perspective, the paper extends previous research on employees using Adaptation-level Theory (Walker, 2017) along with the Motivationhygiene Theory of Herzberg (1964), through which we hope to facilitate an understanding of the implications of job insecurity and job instability regarding job satisfaction in a competitive working environment. The authors propose an original model that allows for the assessment of influential factors regarding general job satisfaction amongst Romanian employees. With the goal of enhancing employee wellbeing, the paper reveals from a managerial perspective the ways in which job insecurity and job instability influence job satisfaction amongst Romanian employees during the COVID-19 pandemic, after which we propose possible solutions for alleviating and overcoming the challenges and insecurity that employees face.

Section 2 describes concepts related to job insecurity and job instability and general job satisfaction as well as associated components along with their interdependence. Section 3 presents the research methodology and the proposed model of analysis, while Section 4 tests the hypotheses and discusses the results. The paper concludes with theoretical and managerial implications, limitations, and perspectives.

\section{THEORETICAL BACKGROUND}

\subsection{Job insecurity and job instability}

Job insecurity refers to the potential concern of individuals that they might lose their job. It is an experience that engenders stress, anxiety, fear, and other negative emotions (Greenhalgh \& 
Rosenblatt, 2010; Wilson et al., 2020; Zhang et al., 2020). These responses are generated by the lack of predictability concerning the future job evolution of employees, rendering them incapable of influencing the development of the situation in any manner and forcing them to simply adapt to it (Vander Elst et al., 2013). Job insecurity differs according to socio-demographic characteristics of individuals: age, gender, education, state of career (Metin Camgoz et al., 2016; Erdogan et al., 2020; Salas-Nicás et al., 2020); field of activity, position within the organisation as well as size and level of the organisation's competitiveness (Petitta \& Jiang, 2020). Social, economic-financial and/or sanitary crises also influence job security (Gasparro et al., 2020; Wilson et al., 2020).

The study of job insecurity has also been approached from the perspective of gender differences between employees. Compared with male employees, female employees were once less inclined towards turnover intention when the workplace became insecure (Metin Camgoz et al., 2016). Job insecurity is more prevalent also among youth at the beginning of their career (Salas-Nicás et al., 2020), among the elderly approaching retirement, as well as among those who no longer have many promotion opportunities left (Pickard, 2019) and are less competitive. Moreover, strategic decisions with a significant impact on organisational success may make employees vulnerable in cases of failure (Shkoler \& Tziner, 2020). The moment a climate of insecurity or instability occurs on an organisational level, the organisation's productivity and competitiveness are directly affected (Erlinghagen, 2007).

Job security constitutes a crucial factor in determining job satisfaction, not only for employees with a larger degree of training, who theoretically could easily find another position in case of job loss, but also for employees who do not fit into this category. Managers monitor improvements in employee job satisfaction, as this attitude overwhelmingly determines the reduction of absenteeism as well as the frequency of turnover intention (Wilczyska, 2016). Satisfaction also favours efficient task completion and competitiveness as well as increases positive employee orientation towards clients (Singh \& Das, 2013; Park et al., 2020).

Changes in job stability and its implications in terms of job satisfaction have been approached from the point of view of Adaptation-level Theory (Ritter et al., 2016; Walker, 2017), a framework based on the premise that individuals make decisions concerning a stimulus according to their previous experience. Employees adapt in various ways to the influence of stress-generating factors, a lack of clarity concerning their role, or to role conflicts, all of which impact negatively both on job satisfaction and employee wellbeing (Shkoler \& Tziner, 2020). The speed at which employees return to a high satisfaction level in their work after a disruption by potential negative or harmful influence on the workplace is an important factor (Ritter et al., 2016; Nemteanu \& Dabija, 2020; 2021).

Job insecurity has been previously studied from the perspective of the Transactional Theory of Stress and Coping (Lazarus \& Folkman, 1984). According to this theory, job insecurity is perceived as a stressor and a source of anxiety due to the possibility of job loss (Debus et al., 2019; Yeves et al., 2020). Job insecurity generates negative stress on results and work attitudes such as job satisfaction, leading to poor performance (Cheng \& Chan, 2008). The impact of job security on job satisfaction has also been studied from the standpoint of Herzberg's Motivation-hygiene Theory (Herzberg, 1964), which distinguishes between psychological and hygienic factors (Byrne, 2006; Wilczyska, 2016). Psychological factors are the motivators that contribute to increased 
satisfaction, whereas physical or hygiene factors lead to decreased job satisfaction (Herzberg, 1964; Herzberg et al., 2010; Tziner et al., 2019). If job security constitutes a motivating factor in enhancing job satisfaction (Matei \& Abrudan, 2016; Wilczyska, 2016), the lack of stability and job insecurity are the two vectors exerting a negative impact on job satisfaction (Reisel et al., 2010), namely the hygiene factors (Byrne, 2006; Sloan et al., 2020).

Employee perception that the workplace is no longer stable highlights a significant impact on their individual wellbeing (Salas-Nicás et al., 2018; Wilson et al., 2020). If job insecurity is the employee's internal perception, job instability is generated by objective conditions that reduce the workforce or by the possibility of job loss in the future (Reisel et al., 2010). Job instability has similar effects to job insecurity and constitutes an economic stressor with significant implications on employee's wellbeing, competitiveness, and mental health (Landsbergis et al., 2012). For most employees, the workplace constitutes their only source of income; for this reason, job security comes as a high priority (Keim et al., 2014; Wilson et al., 2020). Amongst European countries, there is a stark contrast in the perception of job instability. Therefore, countries with a high unemployment rate reveal an increased number of employees in an unstable workplace, having signed work contracts for a predetermined time (Keim et al., 2014; Nemteanu \& Dabija, 2020).

Companies react to changes in the external environment by channelling their efforts to improve human resource practices, by recruiting and selecting the best candidates, but also by improving processes concerning performance and current employees (Osoian \& Zaharie, 2009). In this manner, employees with higher qualifications and competencies are more assured concerning their workplace and security even in unfavourable conditions (Erlinghagen, 2007). The nature of tenure and fixed-term employment contracts also implies a direct effect on security and perception of job stability (Salas-Nicás et al., 2020). Due to the global sanitary crisis generated by the COVID-19 pandemic, job insecurity has become an uncontested reality on a global scale (Fernandes, 2020; Gasparro et al., 2020; Wilson et al., 2020). This insecurity is associated with a great fear of COVID-19 as there is no certainty regarding treatments and recovery rate and due to the fact that contracting it at the workplace is positively correlated with job insecurity (Gasparro et al., 2020). In this context, recent research highlights the direct link between job instability (Sasaki et al., 2020) and the job insecurity felt by the employee (Gasparro et al., 2020; Wilson et al., 2020). Based on these aspects, the following hypothesis are distinguished:

H1: In the COVID-19 pandemic, employee perception regarding job instability is correlated with job insecurity.

\subsection{General job satisfaction}

Job satisfaction represents one of the most important topics tackled by the literature on human resources (Wnuk, 2017) and the core element of organisational development (Walker, 2017). It is of great theoretical and managerial importance, and it has multiple implications on heavy work investment, on increasing employee performance (Wnuk, 2019), and on reducing the turnover intention (Zaharie et al., 2018). From an employee perspective, general job satisfaction is composed of satisfaction with their work, satisfaction with supervisor support, and satisfaction with promotion opportunities (Singh \& Das, 2013). Job satisfaction constitutes an attitudinal vector (Walker, 2017). Maintaining employee satisfaction regarding the work done is a central 
desideratum of human resource management regarding competitiveness (Elrehail et al., 2019). This attitude can be enhanced by innovation-based human resource management (Lasisi et al., 2020) or an internal marketing orientation (Nemteanu \& Dabija, 2021). Job satisfaction can be jeopardized by a series of individual and organisational factors. These factors include job insecurity, job instability (Reisel et al., 2010), lack of tenure employee contracts, and many responsibilities (Gerich \& Weber, 2020), etc. Indeed, job security may influence differently job satisfaction, job productivity (Kuvalekar \& Lipnowski, 2020), heavy work investment, or turnover intention (Metin Camgoz et al., 2016; Nemteanu \& Dabija, 2020), as it is the crucial premise on which employee satisfaction develops with regard to the work done and it is the way positive results are obtained. The lack of security engenders dissatisfaction and leads to negative effects (Byrne, 2006; Wilczyska, 2016; Wilson et al., 2020) and behaviours such as turnover intention (Metin Camgoz et al., 2016; Nemteanu \& Dabija, 2020), task performance or counterproductive behaviour (Nemteanu \& Dabija, 2021)

H2a: Job insecurity is correlated with job satisfaction.

From the perspective of the supervised employee, job satisfaction considers the superior's attitude towards his or her subordinate (McCormack et al., 2006). The organisational support perceived by the employee through supervisory care towards the work done is positively correlated with employee job satisfaction (Gillet et al., 2013); simultaneously, it contributes to diminishing job insecurity (Chen et al., 2013). When employees feel insecure regarding their workplace, they will manifest a lower level of job satisfaction and will evaluate supervisor performance negatively (Feng et al., 2008; Tecău et al., 2020).

H2b: Job insecurity is correlated with employee satisfaction and supervisory support.

In relation to employee growth opportunities within the organisation, an important role is played by age and own perception regarding employability, which constitutes a mix of competencies and employee knowledge (Sloan et al., 2020). Employability plays a significant mediating role in the relation between job security and job satisfaction (Yeves et al., 2019). If insecurity produces adverse effects, job security helps the employee feel appreciated, which is a crucial aspect for obtaining efficiency and organisational competitiveness. Promotion opportunities, acknowledgement, and participation in decision-making are directly influenced by job security, thus contributing to job satisfaction (Mehrabian et al., 2013).

H2c: Job insecurity is correlated with employee's growth opportunities satisfaction.

Employees who benefit from job stability are more satisfied with the work done (SanchezSanchez \& Fernandez Puente, 2020), are more committed to the organisation and service delivery compared with their peers with fixed-term employee contracts (Sancha et al., 2019). The lack of job stability is negatively correlated with job satisfaction and affective organisational investment; the link is stronger/more intense in employees with fixed-term employment contracts or in employees working for an intermediary than in the case of employees with employment contracts signed directly by the employer (be it fixed-term or tenured) (Tecău et al., 2020).

H3a: Job instability is correlated with job satisfaction. 
Moreover, job satisfaction is positively correlated with job stability (Wilczyska, 2016) along with supervisory support (Gordon et al., 2019). From an employee standpoint, satisfactory supervision constitutes a facilitator of integration within the organisation and the way the sense of belonging and even identity may be developed (Morrow et al., 2005). Therefore, job instability or insecurity may diminish the degree of employee satisfaction with supervision.

H3b: Job instability is correlated with employee satisfaction with supervision.

Older studies suggested that employee perception regarding job instability is lower in employees with higher qualifications, as they have access to more promotion opportunities within the organisation. They manage to easily find another job in the industry or related fields (Erlinghagen, 2007). Another perspective, a more recent one, is that both employees with a lower degree of employability and overqualified employees tend to present a high level of job instability in the absence of promotion opportunities (Peiró et al., 2012). In emerging countries such as Romania, Cyprus, Turkey, and Peru, the incidence of overqualified employees is higher; the results of this study reflect that such employees tend to willingly quit their job (Erdogan et al., 2020). The importance of job stability, but also the prospect of promotion opportunities, is vital for employees, it being more relevant than the monthly remuneration in itself (Ali \& Ahmad, 2017). To enhance job satisfaction, career advancement opportunities must be the result of a stable work environment (Origo \& Pagani, 2009) and of a fair system of promotion (García-Izquierdo et al., 2012). Based on these considerations, we distinguish the following hypothesis:

$\mathrm{H} 3 \mathrm{c}$ : Job instability is correlated with employee satisfaction with promotion opportunities.

\subsection{RESEARCH CONTEXT AND MODEL DEVELOPMENT}

According to the data available in the summer of 2020, it is considered that the ubiquitous spread of the new COVID-19 virus started approximately in December 2019 (WHO, 2020; Sohrabi et al., 2020). The sanitary crises imposed a series of restrictive measures adopted by the governments of many states in a desperate attempt to counteract the effects, and especially outcomes of this pandemic (Djalante et al., 2020; Thomas et al., 2020).

On 1 April 2020, 81\% of the employees on a global scale worked in countries that imposed restrictive measures concerning the physical conduct of activities in traditional workspaces (ILO, 2020), like offices, thus encouraging remote work teleworking (Baert et al., 2020). Isolating the employees to their homes allows not only to obtain important cost savings for the organisations (Curtis, 2020) but also the carrying out of activities by employees on condition of safety and job security (Belzunegui-Eraso \& Erro-Garcés, 2020; Bocean et al., 2020; Cirrincione et al., 2020). Organisations seek viable solutions to permanently ensure employee safety and security to diminish the risk of contamination (Béland et al., 2020; ILO, 2020) and to facilitate the enhancement of employee satisfaction with the work done to avoid burnout (Zhang et al., 2020). 


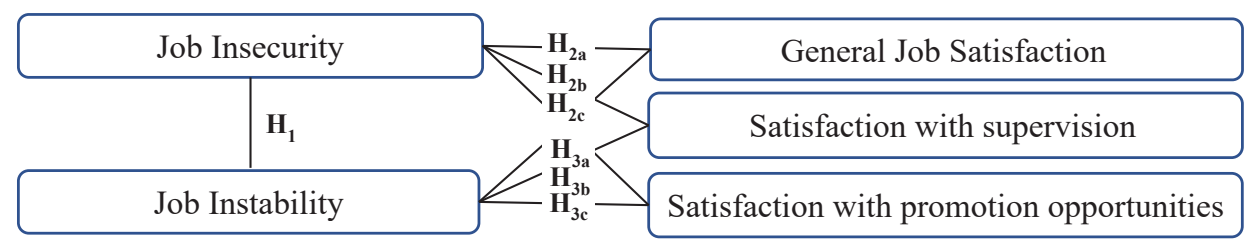

Fig. 1 - The influence of job insecurity and instability on job satisfaction. Source: own research

Previous research includes Romania as a former communist country that is undergoing a transition from a non-market and centralized economy to a free market economy (Shkoler et al., 2017; Nemteanu \& Dabija, 2020). Considering the context of the COVID-19 pandemic, the authors resorted to analysing the influence of job insecurity and job instability on job satisfaction (Figure 1) in Romania, an emerging economy greatly affected by the recent sanitary crisis. Since April 2020, Romania is in a vulnerable situation, having registered the highest number of COVID-19 related deaths among Central and Eastern Europe in April 2020 (Nemteanu \& Dabija, 2021), leading to the 1,029,304 confirmed cases, 53,043 cases per 1 million inhabitants, and 26,232 deaths in April 2021 (Google COVID-19, 2021). In the first trimester of 2020, the employment rate (ages 15-64) was $65.4 \%$ in Romania, decreasing by $1.6 \%$ compared to the previous trimester (INS, 2020). Employee insecurity and their perception of job instability are a reality in the context of COVID-19 (Gasparro et al., 2020; Wilson et al. 2020) due to the changes in the workplace that engender uncertainty regarding fear of infection (Beland et al., 2020), and job insecurity in industries profoundly affected (Fernandes, 2020), or domains wherein unemployment is rising (Couch et al., 2020); this situation negatively influences job satisfaction (Zhang et al., 2020).

\section{RESEARCH OBJECTIVES, METHODOLOGY AND DATA}

To identify measures in which job instability and job insecurity influence job satisfaction, satisfaction with supervision, and promotion opportunities in the context of the sanitary pandemic generated by COVID-19, the authors resorted to implementing exploratory quantitative research among employees in Romania. This was based on the investigation model, using selfadministered online questionnaires as a tool. The invitation to participate was disseminated by the authors on different social media platforms (Facebook, LinkedIn, and Twitter), but also educational platforms and directly to various organisations. The questionnaire was filled out by Romanian residents with an employment contract valid at the time of response. The data were collected in May-July 2020, comprised of 568 valid questionnaires. Sampling was of convenience, aiming to maintain sampling according to age and gender following the distribution specified in the Statistical Yearbook (INS, 2020).

\subsection{Variable measurement and data analysis}

The operationalisation of the investigated domains presented in Figure 1 was carried out according to literature specifications. The concept of job insecurity was analysed both as a multidimensional concept and a global concept; measuring it as a global concept was recommended 
by several researchers who propose that multidimensional measurement may diverge from the basic meaning of the construct (Vader Elst et al., 2015). The global concept of job insecurity was measured both based on a multiple-item questionnaire (Vader Elst et al., 2015; Bocean et al., 2020) and a single item in previous literature (Strazdins et al., 2004; Gasparro et al., 2020). In this respect, to evaluate the impact of job insecurity in the context of the COVID-19 pandemic from employee's perspective, the authors introduced the following item, "I felt directly affected when it comes to job security". Job instability was analysed less in the previous research from an employee perception perspective - it being analysed as frequent change of employment (Wille et al., 2010), which is the reason why the authors have proposed the analysis of this concept from an employee's perspective in the context of COVID-19 through the following item "I felt uncertainty regarding job security".

A plethora of factors composing job satisfaction have been analysed in the academic literature (Zaharie et al., 2018). Previous literature emphasizes various components of job satisfaction concerning job insecurity or job instability, such as general job satisfaction (Byrne, 2006; Wilczyska, 2016; Wilson et al., 2020), satisfaction with supervisory support (Feng et al., 2008), and satisfaction with promotion opportunities (Mehrabian et al., 2013). To analyse job satisfaction, the authors have employed the general job satisfaction scale, which includes employee perception on satisfaction regarding own work ("I am satisfied with my work"), supervision ("I am generally pleased with my supervisor"), promotion opportunities ("I am pleased with the promotion opportunities offered by this workplace”) (Singh \& Das, 2013).

\subsection{Sample structure}

The questionnaire was filled out by Romanian employees with an employment contract working in different organisations (Table 1). Females make up $65.49 \%$ of the sample, respondents having mostly higher education (69.07\%), being employed by local companies (48.11\%). The sample is represented mostly by respondents under 40, 202 aged under 25 and 177 aged between 25 and 40 .

Tab. 1 - Sample structure. Source: own research

\begin{tabular}{|l|l|l|l|l|l|l|}
\hline \multirow{2}{*}{ Gender } & \multicolumn{2}{l}{ Male } & \multicolumn{2}{l|}{ Female } & \multicolumn{2}{l|}{ Total } \\
\cline { 2 - 8 } & $\mathrm{n}$ & $\%$ & $\mathrm{n}$ & $\%$ & $\mathrm{n}$ & $\%$ \\
\hline Under 25 years & 73 & 12.85 & 128 & 22.53 & 202 & 26.05 \\
\hline 25-40 years & 51 & 8.97 & 126 & 22.18 & 177 & 31.16 \\
\hline Over 40 years & 52 & 9.15 & 96 & 16.90 & 148 & 35.56 \\
\hline Vocational education & 5 & 0.88 & 6 & 1.05 & 11 & 1.93 \\
\hline Upper secondary education & 58 & 10.21 & 104 & 18.30 & 162 & 28.52 \\
\hline Higher education & 131 & 23.06 & 261 & 45.95 & 392 & 69.07 \\
\hline Employed in public institutions & 14 & 2.46 & 59 & 10.38 & 73 & 12.85 \\
\hline Employed in local private companies & 102 & 17.95 & 177 & 31.16 & 279 & 49.11 \\
\hline Employed in foreign private companies & 63 & 11.09 & 105 & 18.48 & 168 & 29.57 \\
\hline Total & 194 & 34.15 & 374 & 65.85 & 568 & 100.0 \\
\hline
\end{tabular}




\section{RESULTS AND DISCUSSION}

In this research, data collection was based on a 1-5 Likert scale, ranging from (1) strongly disagree to (5) strongly agree, in conformity to previous research of job satisfaction or job insecurity (Singh \& Das, 2013; Gasparro et al., 2020). Norman (2010) suggests that Likert data can be analysed using parametric tests. Previous academic research indicates Pearson parametric correlation coefficient is suitable for Likert scale data in social and business research (Malhotra \& Birks, 2007; Murray, 2013). The results of the Pearson Correlation Analysis are shown in Table 2.

Tab. 2 - Correlation analysis results. Source: own research

\begin{tabular}{|l|l|l|l|l|l|l|l|}
\hline Variables & 1 & 2 & 3 & 4 & 5 & Mean & Std. Dev. \\
\hline 1. Job insecurity & 1 & & & & & 2.71 & 1.452 \\
\hline 2. Job instability & $0.693^{* *}$ & 1 & & & & 2.40 & 1.382 \\
\hline $\begin{array}{l}\text { 3. General job satisfac- } \\
\text { tion }\end{array}$ & -0.050 n.s. & $-0.141^{* *}$ & 1 & & & 4.07 & 0.872 \\
\hline $\begin{array}{l}\text { 4.Satisfaction with su- } \\
\text { pervision }\end{array}$ & $-0.075^{*}$ & $-0.147^{* *}$ & $0.554^{* *}$ & 1 & & 4.03 & 0.988 \\
\hline $\begin{array}{l}\text { 5.Satisfaction with pro- } \\
\text { motion opportunities }\end{array}$ & $-0.114^{* *}$ & $-0.126^{* *}$ & $0.608^{* *}$ & $0.604^{* *}$ & 1 & 3.62 & 1.178 \\
\hline
\end{tabular}

Note: ${ }^{*} \mathrm{p}<0,05 ;{ }^{*} \mathrm{p}<0,001 ;$ n.s. - not significant; Std. Dev. - Standard deviation.

There is an enormously significant and positive link $\left(0.693^{* *}\right)$ between perceived job insecurity and instability, which allows for the validation of the $\mathrm{H} 1$ hypothesis. This result confirms the strong link discussed in theory concerning job insecurity and job instability. The fear generated by the possibility of job loss is directly proportional to the reality of an uncertain future in the workplace or an unstable work context (Landsbergis et al., 2012).

There is an inversely proportional correlation, lower in terms of significance $\left(-0.075^{*}\right)$, between job insecurity and job satisfaction with supervision, which allows for the partial validation of the $\mathrm{H} 2 \mathrm{~b}$ hypothesis. A negative correlation (inversely proportional) means that job insecurity increases as satisfaction with supervision decreases. This result confirms similar results of previous research, such as those obtained by Chen et al. (2013) and Di Stephano et al. (2020), which stress the crucial role that social support plays in reducing employees' job insecurity and its impact on job satisfaction.

Table 3 indicates that job insecurity is negatively correlated to employee satisfaction regarding growth opportunities within the organization $\left(-0.114^{* *}\right)$; the link is less intense and significant, which allows for the partial validation of the H2c hypothesis. General respondent satisfaction with work done during the COVID-19 pandemic is by no means determined by insecurity regarding work done, which serves to invalidate the H2a hypothesis. Previous studies have analysed the link between job satisfaction as a general construct and job insecurity, highlighting significant yet weak links between the two constructs. Zheng et al. (2014) emphasize a weaker although significant and inversely proportional correlation between job insecurity and job satisfaction. Nevertheless, the results of these researchers show that job satisfaction does not decrease as job insecurity increases, with only the satisfaction with supervision as well 
as promotion opportunities significantly affected. It is essential that employers recognize in advance the factors and elements which could generate job insecurity, since these could constitute early signals of a possible decrease in job satisfaction (Di Stephano et al., 2020). In response to diminished job satisfaction, internal marketing orientation (Nemteanu \& Dabija, 2021) and an innovative-based human resource management approach could improve employee performance and competitiveness (Elrehail et al., 2019).

There are relatively weak, inversely proportional yet enormously significant correlations $(-0.141 * *)$ between employee perceptions regarding job instability and job satisfaction, which serves to validate the $\mathrm{H} 3$ a hypothesis. The link between job instability and job satisfaction has also been approached by other authors who have highlighted significant and negative links between the two variables (Dulebohn et al., 2012; Zheng et al., 2014; Debus et al., 2019). Job instability is negatively correlated (inversely proportional) although enormously significant to employee satisfaction regarding their superiors (supervision), which serve to validate the H3b hypothesis $\left(-0.147^{* *}\right)$. Finally, the negative and enormously significant correlation $\left(-0.126^{* *}\right)$ between job instability and job satisfaction with promotion opportunities validates the H3c hypothesis. The relation between job satisfaction with promotion opportunities and job instability within the organisation was found to be significant and reduced in intensity, yet inversely proportional in effect.

Employee behaviour towards change and job (in)stability has been the objective of countless studies and research, many of which approach satisfaction based on Adaptation-level Theory (Ritter et al., 2016). The authors highlight the finding that due to changes of any kind in the workplace, employees tend to reveal for a relatively long time a low level of job satisfaction. Later, the level of satisfaction towards work done and towards the organisation reverts to original values before these changes (Walker, 2017).

According to Adaptation-level Theory, the job insecurity and job instability of the employee within the organisation are two vectors of negative impact on job satisfaction. When the level of employee security towards the work done decreases, adapting to the new organisational context manifests in a low level of job satisfaction felt towards superiors (supervision) and promotion opportunities. Job insecurity engenders a decrease in job satisfaction regarding the employee's own work done. From the point of view of the Transactional Theory of Stress and Coping (Lazarus \& Folkman, 1984), research results have confirmed the negative impact on job satisfaction of the economic stressors job instability and job insecurity, an aspect which has been previously highlighted in the literature (Yeves et al., 2020). The results confirm discussions based on Herzberg's Motivation-hygiene Theory (Herzberg, 1964), according to which job insecurity and job instability are considered negative hygiene factors of job satisfaction (Byrne, 2006).

\section{CONCLUSION}

The results of this research carried out during the sanitary crisis and the COVID-19 pandemic extends the studies focused on human resource management, making an original contribution to better understanding the effects of job insecurity and job instability on the work done by employees of various companies on their perceived satisfaction with their work, their relationship 
with supervisors as well as the promotion opportunities within the organisation in question. The research extends the studies focused on Adaptation-level Theory in terms of employee behaviour which highlight job instability and job insecurity as negative stimuli affecting the reduction of job satisfaction as a result of adaptation to the new conditions engendered by the sanitary crisis. The paper also brings an essential contribution in extending Herzberg's Motivation-hygiene Theory (Herzberg, 1964), as job insecurity proves to be a negative (hygiene) factor that significantly contributes to the reduction of job satisfaction. The results of the correlation analysis confirmed the link between perceived employee insecurity and satisfaction with supervisors, but also with promotion opportunities in the context of the sanitary crisis. Moreover, a negative link was found in the empirical data analysis between job instability and job satisfaction.

From a managerial perspective, the paper highlights the correlation between job insecurity and job instability, and perceived employee satisfaction within the organisations in question. It is important that employers understand the elements contributing to the decrease of employee satisfaction and that they identify in advance such potential situations and take proper measures. Superiors may offer employees competent supervision and ideas for the completion of tasks that occur during their work activity. At the same time, they may offer their employees moral or social support through communication and even professional counselling, or by providing support and guidance with task completion. Job instability may be diminished by converting fixed-term employee contracts into tenured ones or by providing guarantees and a more evident career track which employees could undertake to accede to higher positions and consolidate their status within the company. In the context of socio-economic crises, but also of sanitary ones, identifying the most appropriate solution for employee well-being should constitute employers' primary objective. Even converting a position from full-time to part-time or flexitime, supporting teleworking, and avoiding bouts of unemployment may increase leverage in enhancing employee satisfaction, serving to reduce and even eliminate risks associated with turnover intention. Our empirical results reveal that job insecurity is correlated to reduced intensity, yet significant and inversely proportional with job satisfaction, with satisfaction towards supervision, and promotion opportunities. Organisational competitiveness is strongly related to employee well-being and job satisfaction. Reduced job satisfaction should become a high priority from a managerial perspective, as it carries negative implications on employee work and organisational competitiveness. We consider that employer efforts must head towards diminishing not only job instability for the employee, but also insecurity. The employer must define a proper strategy to improve and maintain organisational competitiveness in this respect and prioritise the identification of measures that can contribute to maintaining and significantly enhancing employee satisfaction, particularly in the context of sanitary crises such as the one generated by the COVID-19 virus.

Despite the clear gaps filled with this research, a series of limitations can be identified, firstly that this paper focuses only on employees in Romania. Future research may also take into consideration a contrastive approach among various markets (emerging and developed). In addition, a limitation regarding the data collection consists stems from featuring respondents from a variety of organisational categories. More insights could be provided in future research through comparative studies among different types of organisations, for instance, differences 
in job insecurity and job instability in public institutions versus private companies. Another limitation lies in the fact that although the research was carried out during the sanitary crisis generated by the COVID-19 pandemic, the respondents were not solicited to emphasize the extent to which they have been affected by this crisis or the way they believe their career perspectives might change after the sanitary crisis is over. Future research will approach employee perceptions in various institutions (public, Romanian companies, foreign companies, non-profit organisations, etc.) to point out potential differences regarding employee satisfaction regarding the three components related to work done. Future research could be carried out to correlate/ link the impact of remote work (teleworking) on employee satisfaction in relation to the sanitary crisis generated by the COVID-19 pandemic. Finally, another limitation is the limited number of variables, with job satisfaction being a variable that is influenced by a large number of factors from an organisational competitiveness perspective. Future research could assess the impact of other variables such as work conditions, domain influence, organizational culture, wages or other variables connected to job instability and job insecurity.

Acknowledgement: This work was made possible with the financial support of the Operational Programme Human Capital 2014-2020, under the project number POCU 123793 with the title "Researcher, future entrepreneur - New Generation."

\section{References}

1. Ali, M. Z., \& Ahmad, N. (2017). Impact of pay promotion and recognition on job satisfaction (A study on banking sector employees karachi). Global Management Journal for Academic \& Corporate Studies, 7 (2), 131-141.

2. Baert, S., Lippens, L., Moens, E., Weytjens, J., \& Sterkens, P. (2020). The Covid-19 Crisis and Telework: A Research Survey on Experiences, Expectations and Hopes. IZA Discussion Paper, 13229 Retrieved August 14, 2020, from https://ssrn.com/abstract=3596696

3. Bartik, A. W., Bertrand, M., Cullen, Z., Glaeser, E. L., Luca, M., \& Stanton, C. (2020). The impact of COVID-19 on small business outcomes and expectations. Proceedings of the National Academy of Sciences, 17 (30) 17656-17666. http://dx.doi.org/10.1073/pnas.2006991117

4. Béland, L. P., Fakorede, O., \& Mikola, D. (2020). Short-Term Effect of COVID-19 on SelfEmployed Workers in Canada. Canadian Public Policy, 46 (1), 66-81. http://dx.doi.org/10.3138/ cpp.2020-076

5. Belzunegui-Eraso, A., \& Erro-Garcés, A. (2020). Teleworking in the Context of the Covid-19 Crisis. Sustainability, 12 (9), 3662. http://dx.doi.org/10.3390/su12093662

6. Bocean, C. G., Vărzaru, A. A, Băndoi, A., \& Sitnikov, C. S. (2020). Transversal Analysis of Predictors, Moderators and Related Effects of HWI. Amfiteatru Economic, 22 (14), 973-992. http://dx.doi.org/10.24818/EA/2020/S14/973

7. Böckerman, P., Ilmakunnas, P., \& Johansson, E. (2011). Job security and employee well-being: Evidence from matched survey and register data. Labour Economics, 18 (4), 547-554. http:// dx.doi.org/10.1016/j.labeco.2010.12.011

8. Byrne, M. (2006). The Implications of Herzberg's "Motivation-Hygiene" Theory for Management in the Irish Health Sector. The Health Care Manager, 25 (1), 4-11. 
9. Cheng, G. H. L., \& Chan, D. K. S. (2008). Who suffers more from job insecurity? A meta-analytic review. Applied Psychology, 57 (2), 272-303. http://dx.doi.org/10.1111/j.14640597.2007.00312.x

10. Cheng, T., Mauno, S., \& Lee, C. (2014). Do Job Control, Support, and Optimism Hel Job Insecure Employees? A Three-Wave Study of Buffering Effects on Job Satisfaction, Vigor and Work-Family Enrichment. Social Indicators Research, 118, 1269-1292. http://dx.doi.org/10.1007/ s11205-013-0467-8

11. Cirrincione, L., Plescia, F., Ledda, C., Rapisarda, V., Martorana, D., Moldovan, R. K., Theodoridou, K., \& Cannizzaro, E. (2020). COVID-19 Pandemic: Prevention and Protection Measures to Be Adopted at the Workplace. Sustainability, 12 (9), 3603. http://dx.doi. org $/ 10.3390 /$ su12093603

12. Couch, K. A., Fairlie, R. W., \& Xu, H. (2020). The Impacts of COVID-19 on Minority Unemployment: First Evidence from April 2020 CPS Microdata. Retrieved August 14, 2020, from http://dx.doi.org/10.2139/ssrn.3604814

13. Curtis, M. (2020). (re)Awakening to the benefits and climate impacts of telework during COVID-19. UC San Diego: Climate Science and Policy. Retrieved August 14, 2020, from https://escholarship.org/uc/item/7nf8k2q6

14. Debus, M. E., Kleinmann, M., König, C. J., \& Winkler, S. (2019). Being Tough Versus Tender: The Impact of Country-Level and Individual Masculinity Orientations as Moderators of the Relationship between Job Insecurity and Job Attitudes. Applied Psychology. 1-37. http://dx.doi. org/10.1111/apps.12189

15. Djalante, R., Shaw, R., \& DeWit, A. (2020). Building resilience against biological hazards and pandemics: COVID-19 and its implications for the Sendai Framework. Progress in Disaster Science, 6, 100080. https://doi.org/10.1016/j.pdisas.2020.100080

16. Dulebohn, J. H., Bommer, W. H., Liden, R. C., Brouer, R. L., \& Ferris, G. R. (2011). A Meta-Analysis of Antecedents and Consequences of Leader-Member Exchange. Journal of Management, 38 (6), 1715-1759. http://dx.doi.org/10.1177/0149206311415280

17. Elrehail, H., Harazneh, I., Abuhjeeleh, M., Alzghoul, A., Alnajdawi, S., \& Ibrahim, H.M.H. (2019). Employee satisfaction, human resource management practices and competitive advantage: The case of Northern Cyprus. European Journal of Management and Business Economics, 29 (2), 125-149.

18. Erdogan, B., Karakitapoğlu-Aygün, Z., Caughlin, D. E., Bauer, T. N. \& Gumusluoglu, L. (2020). Employee overqualification and manager job insecurity: Implications for employee career outcomes. Human Resource Management. 59 (6), 555-567. http://dx.doi.org/10.1002/ hrm. 22012

19. Erlinghagen, M. (2007). Self-Perceived Job Insecurity and Social Context: A Multi-Level Analysis of 17 European Countries. European Sociological Review, 24 (2), 183-197. http://dx.doi. org/10.1093/esr/jcm042

20. Feng, D. D., Lu, C. Q., \& Siu, O. L. (2008). Job insecurity, well-being, and job performance: The role of general self-efficacy. Acta Psychologica Sinica, 40 (4), 448-455. https://doi. org/10.3724/SP.J.1041.2008.00448

21. Fernandes, N. (2020). Economic Effects of Coronavirus Outbreak (COVID-19) on the World 
Economy. IESE Business School Working Paper No. WP-1240-E. http://dx.doi.org/10.2139/ ssrn. 3557504

22. García-Izquierdo, A. L., Moscoso, S., \& Ramos-Villagrasa, P. (2012). Reactions to the fairness of promotion methods: Procedural justice and job satisfaction. International Journal of Selection and Assessment, 20 (4), 394-403. http://dx.doi.org/10.1111/ijsa.12002

23. Gasparro, R., Scandurra, C., Maldonato, N. M., Dolce, P., Bochicchio, V., Valletta, A., Sammartino, G., Sammartino, P., Mariniello, M., Espedito di Lauro, A., \& Marenzi, G. (2020). Perceived Job Insecurity and Depressive Symptoms among Italian Dentists: The Moderating Role of Fear of COVID-19. International Journal of Environmental Research and Public Health, 17, 5338. http://dx.doi.org/10.3390/ijerph17155338

24. Gerich, J., \& Weber, C. (2020). The Ambivalent Appraisal of Job Demands and the Moderating Role of Job Control and Social Support for Burnout and Job Satisfaction. Social Indicators Research, 148, 251-280.

25. Gillet, N., Colombat, P., Michi Nov, E., Pronost, A.-M., \& Fouquereau, E. (2013). Procedural justice, supervisor autonomy support, work satisfaction, organizational identification, and job performance: the mediating role of need satisfaction and perceived organizational support. Journal of Advanced Nursing, 69 (11), 2560-2571. http://dx.doi.org/10.1111/jan.12144

26. Google COVID-19 (2021). Coronavirus COVID-19 Cases daily updates. Retrieved August 14, 2020, from https://news.google.com/covid19/map?hl=en-US\&gl=US\&ceid=US:en

27. Gordon, S., Adler, H., Day, J., \& Sydnor, S. (2019). Perceived supervisor support: A study of select-service hotel employees. Journal of Hospitality and Tourism Management, 38, 82-90. http:// dx.doi.org/10.1016/j.jhtm.2018.12.002

28. Greenhalgh, L., \& Rosenblatt, Z. (2010). Evolution of Research on Job Insecurity, International Studies of Management and Organization, 40 (1), 6-10.

29. Hassard, J., \& Morris, J. (2017). Corporate restructuring, work intensification and perceptual politics: Exploring the ambiguity of managerial job insecurity. Economic and Industrial Democracy, 41 (2), 251-253. http://dx.doi.org/10.1177/0143831x17710733

30. Herzberg, F. (1964). The Motivation-Hygiene Concept and Problems of Manpower. Personnel Administration, 27 (1), 3-7.

31. Herzberg, F., Mausner, B., \& Bloch Snyderman, B. (2010). The Motivation to Work, first published in 1959: Transaction Publishers.

32. ILO (2020). ILO Monitor: COVID-19 and the world of work. Fifth edition Retrieved August 14, 2020, from https://www.ilo.org/wcmsp5/groups/public/@dgreports/@dcomm/ documents/briefingnote/wcms_749399.pdf

33. INS (2020). Press Release 167/26.6.2020. National Institute of Statistics. Retrieved August 14, 2020, from https://insse.ro/cms/sites/default/files/com_presa/com_pdf/somaj_tr1r_20.pdf

34. Keim, A. C., Landis, R. S., Pierce, C. A., \& Earnest, D. R. (2014). Why do employees worry about their jobs? A meta-analytic review of predictors of job insecurity. Journal of Occupational Health Psychology, 19 (3), 269-290. https://doi.org/10.1037/a0036743

35. Kuvalekar, A., \& Lipnowski, E. (2020). Job Insecurity. American Economic Journal: Microeconomics, $12(2), 188-229$. 
36. Landsbergis, P. A., Grzywacz, J. G., \& LaMontagne, A. D. (2012). Work organization, job insecurity, and occupational health disparities. American Journal of Industrial Medicine, 57 (5), 495-515. http://dx.doi.org/10.1002/ajim.22126

37. Lasisi, T.T., Ozturen, A., Eluwole, K.K. and Avci, T. (2020). Explicating innovation-based human resource management's influence on employee satisfaction and performance. Employee Relations, 42 (6), 1181-1203. https://doi.org/10.1108/ER-08-2019-0319

38. Lazarus, R. S. \& Folkman, S. (1984). Stress, Appraisal, and Coping. New York: Springer.

39. Malhotra, N. K., \& Birks, D. F. (2007). Marketing Research. An Applied Approach, Third Edition. London: Prentice Hall.

40. Matei, M.-C., \& Abrudan, M. M. (2016). Adapting Herzberg's Two Factor Theory to the Cultural Context of Romania. Procedia - Social and Behavioral Sciences, 221, 95-104. http://dx.doi. org/10.1016/j.sbspro.2016.05.094

41. McCormack, D., Casimir, G., Djurkovic, N., \& Yang, L. (2006). The concurrent effects of workplace bullying, satisfaction with supervisor, and satisfaction with co-workers on affective commitment among schoolteachers in China. International Journal of Conflict Management, 17 (4), 316-331. http://dx.doi.org/10.1108/10444060610749473

42. Mehrabian, F., Niroumand, E., Mohamadian, S.K., \& Naghipour, D. (2013). Factors Affecting Job Satisfaction among the Faculty Members at Guilan University of Medical Sciences. Educational Research in Medical Sciences Journal, 2, 14-19.

43. Metin Camgoz, S., Tayfur Ekmekci, O., Bayhan Karapinar, P., \& Kumbul Guler, B. (2016). Job Insecurity and Turnover Intentions: Gender Differences and the Mediating Role of Work Engagement. Sex Roles, 75 (11), 583-598.

44. Morrow, P., Suzuki, Y., Crum, M., Ruben, R., \& Pautsch, G. (2005). The role of leader-member exchange in high turnover work environments. Journal of Managerial Psychology, 20, 681-694.

45. Murray, J. (2013). Likert Data: What to Use, Parametric or Non-Parametric? International Journal of Business and Social Science, 4 (11), 258-264.

46. Nemteanu, M. S., \& Dabija, D. C. (2020). The Influence of Heavy Work Investment on Job Satisfaction and Turnover Intention in Romania. Amfiteatru Economic, 22 (14), 993-1013. http:// dx.doi.org/10.24818/EA/2020/S14/993

47. Nemteanu, M. S., \& Dabija, D. C. (2021). The Influence of Internal Marketing and Job Satisfaction on Task Performance and Counterproductive Work Behavior in an Emerging Market during the COVID-19 Pandemic. International Journal of Environmental Research and Public Health, 18 (7), 3670. https://doi.org/10.3390/ijerph18073670

48. Norman, G. (2010). Likert scales, levels of measurement and the "laws". Advances in Health Sciences Education, 15, 625-632. https://doi.org/10.1007/s10459-010-9222-y

49. Origo, F. \& Pagani, L. (2009). Flexicurity and job satisfaction in Europe: The importance of perceived and actual job stability for well-being at work. Labour Economics, 16 (5), 547-555. http://dx.doi.org/10.1016/j.labeco.2009.02.003

50. Osoian, C. \& Zaharie, M. (2009). Organizational changes in human resource management in a developing country, In: Democritus University of Thrace, 6th International Conference on Management of Technological Changes. Alexandroupolis, Greece. Komotini (Greece): 
Democritus University of Thrace, 569-573.

51. Park, J.-K., Ahn, J., Han, S.-L., Back, K.-J., \& An, M. (2020). Exploring Internal Benefits of Medical Tourism Facilitators' Satisfaction. Journal of Healthcare Management, 65 (2), 90-105. http://dx.doi.org/10.1097/jhm-d-18-00168

52. Peiró, J. M., Sora, B., \& Caballer, A. (2012). Job insecurity in the younger Spanish workforce: Causes and consequences. Journal of Vocational Behavior, 80 (2), 444-453. http://dx.doi. org/10.1016/j.jvb.2011.09.007

53. Petitta, L., \& Jiang, L. (2020). How emotional contagion relates to burnout: A moderated mediation model of job insecurity and group member prototypicality. International Journal of Stress Management, 27 (1), 12-22. https://doi.org/10.1037/str0000134

54. Pickard, S. (2019). Age War as the New Class War? Contemporary Representations of Intergenerational Inequity. Journal of Social Policy, 48 (2), 369-386.

55. Reisel, W. D., Probst, T. M., Chia, S. L., Maloles, C. M., \& König, C. J. (2010). The Effects of Job Insecurity on Job Satisfaction, Organizational Citizenship Behavior, Deviant Behavior, and Negative Emotions of Employees. International Studies of Management \& Organization, 40 (1), 74-91. http://dx.doi.org/10.2753/imo0020-8825400105

56. Ritter, K. J., Matthews, R. A., Ford, M. T., \& Henderson, A. A. (2016). Understanding role stressors and job satisfaction over time using adaptation theory. Journal of Applied Psychology, 101(12), 1655-1669. http://dx.doi.org/10.1037/ap10000152

57. Salas-Nicás, S., Moncada, S., Llorens, C., \& Navarro, A. (2018). Cognitive and affective insecurity related to remaining employed and working conditions: their associations with mental and general health. Journal of Occupational and Environmental Medicine, 60 (11), 589-594. https://doi.org/10.1097/JOM.0000000000001448

58. Salas-Nicás, S., Moncada, S., Llorens, C., Moriña, D., \& Navarro, A. (2020). A complex view of perceived job insecurity: Relationship between three domains and their respective cognitive and affective components. Safety Science, 129, 104796. http://dx.doi.org/10.1016/j. ssci.2020.104796

59. Sancha, C., Wiengarten, F., Longoni, A., \& Pagell, M. (2019). The moderating role of temporary work on the performance of lean manufacturing systems. International Journal of Production Research, 58 (14), 4285-4305. http://dx.doi.org/10.1080/00207543.2019.1651458

60. Sánchez-Sánchez, N., \& Fernandez Puente, A. C. (2020). Public versus Private Job satisfaction. Is there a Trade-off between Wages and Stability? Public Organizations Review, 2021 (1), 1-21. https://doi.org/10.1007/s.11115-020-00472-7

61. Sasaki, N., Kuroda, R., Tsuno, K., \& Kawakami, N. (2020). Fear, Worry and Workplace Harassment Related to the COVID-19 Epidemic Among Employees in Japan: Prevalence and Impact on Mental and Physical Health. Preprint of The Lancet. Retrieved from: http://dx.doi. org/10.2139/ssrn.3569887

62. Shkoler, O., \& Tziner, A. (2020). Leadership Styles as Predictors of Work Attitudes: A Moderated-Mediation Link. Amfiteatru Economic, 22 (53), 164-178. http://dx.doi.org/10.24818/ $\mathrm{EA} / 2019 / 53 / 164$

63. Shkoler, O., Rabenu, E., Vasiliu, C., Sharoni, G., \& Tziner, A. (2017). Organizing the 
Confusion Surrounding Workaholism: New Structure, Measure, and Validation. Frontiers in Psychology, 8, 1803.

64. Singh, R., \& Das, G. (2013). The impact of job satisfaction, adaptive selling behaviors and customer orientation on salesperson's performance: exploring the moderating role of selling experience. Journal of Business \& Industrial Marketing, 28 (7), 554-564. http://dx.doi. org/10.1108/jbim-04-2011-0121

65. Sloan, D., Mikkelson, C. A., \& Văduva, S. (2020). The Importance of Mentorship in Diminishing Workaholism and Increasing Heavy Work Investment: Evidence from the United States. Amfiteatru Economic, 22 (14), 1030-1048. http://dx.doi.org/10.24818/EA/2020/ S14/1030

66. Sohrabi, C., Alsafi, Z., O’Neill, N., Khan, M., Kerwan, A., Al-Jabir, A., \& Agha, R. (2020). World Health Organization declares Global Emergency: A review of the 2019 Novel Coronavirus (COVID-19). International Journal of Surgery. http://dx.doi.org/10.1016/j. ijsu.2020.02.034

67. Strazdins, L., D’Souza, R. M., Lim, L. L. Y., Broom, D. H., \& Rodgers, B. (2004). Job Strain, Job Insecurity, and Health: Rethinking the Relationship. Journal of Occupational Health Psychology, 9 (4), 296-305. https://doi.org/10.1037/1076-8998.9.4.296

68. Tecău, A. S., Constantin, C. P., Lixăndroiu, R. C., Chitu, I. B., \& Brătucu, G. (2020). Impact of the COVID-19 Crisis on Heavy Work Investment in Romania. Amfiteatru Economic, 22(Special Issue No. 14), 1049-1067. https://doi.org/10.24818/EA/2020/S14/1049

69. Thomas, H., Noam, A., Beatriz, K., Anna, P., Toby, P., \& Samuel, W. (2020). Variation in Government Responses to COVID-19. Version 6.0. Blavatnik School of Government Working Paper. Retrieved August 14, 2020, from www.bsg.ox.ac.uk/covidtracker

70. Tziner, A., Buzea, C., Rabenu, E., Shkoler, O., \& Truta, C. (2019). Understanding the Relationship Between Antecedents of Heavy Work Investment (HWI) and Burnout. Amfiteatru Economic, 21 (50), 153-176. http://dx.doi.org/10.24818/EA/2019/50/153

71. Vander Elst, T., De Witte, H., \& De Cuyper, N. (2013). The Job Insecurity Scale: A psychometric evaluation across five European countries. European Journal of Work and Organizational Psychology, 23 (3), 364-380. http://dx.doi.org/10.1080/1359432x.2012.745989

72. Walker, S. (2017). The volatile human: Moderating effects on job satisfaction after job redesign. Academy of Business Research Journal, 3, 28-43.

73. WHO (2020). Coronavirus (COVID-19). World Health Organization. Retrieved August 14, 2020, from https://covid19.who.int

74. Wilczyska, A., Batorski, D., \& Sellens, J. T. (2016). Employment flexibility and job security as determinants of job satisfaction: The case of polish knowledge workers. Social Indicators Research, 126 (2), 633-656. http://dx.doi.org/10.1007/s11205-015-0909-6

75. Wille, B., De Fruyt, F., \& Feys, M. (2010). Vocational interests and Big Five traits as predictors of job instability. Journal of Vocational Behavior, 76 (3), 547-558. http://dx.doi.org/10.1016/j. jvb.2010.01.007

76. Wilson, J. M., Lee, J., Fitzgerald, H. N., Oosterhoff, B., Sevi, B., \& Shook, N. J. (2020). Job Insecurity and Financial Concern During the COVID-19 Pandemic Are Associated with 
Worse Mental Health. Journal of Occupational and Environmental Medicine, 62 (9), 686-691. http:// dx.doi.org/10.1097/jom.0000000000001962

77. Wnuk, M. (2017). Organizational conditioning of job satisfaction. A model of job satisfaction. Contemporary Economics, 11 (1), 31-44. http://dx.doi.org/10.5709/ce.1897-9254.227

78. Yeves, J., Bargsted, M., Cortes, L., Merino, C. \& Cavada, G. (2019). Age and Perceived Employability as Moderators of Job Insecurity and Job Satisfaction: A Moderated Moderation Model. Frontiers in Psychology, 10, 799. http://dx.doi.org/10.3389/fpsyg.2019.00799

79. Zaharie, M., Kerekes, K., \& Osoian, C. (2018). Employee Wellbeing in Health Care Services: The Moderating Role of Job Satisfaction on The Relationship Between Burnout and Turnover. Managerial Challenges of the Contemporary Society. Proceedings; Cluj-Napoca, 11 (2), 124.

80. Zhang, S. X., Liu, J., Afshar Jahanshahi, A., Nawaser, K., Yousefi, A., Li, J. \& Sun, S. (2020). At the height of the storm: Healthcare staff's health conditions and job satisfaction and their associated predictors during the epidemic peak of COVID-19. Brain, Behavior, and Immunity, 87, 144-146. http://dx.doi.org/10.1016/j.bbi.2020.05.010

81. Zheng, X., Diaz, I., Tang, N., \& Tang, K. (2014). Job insecurity and job satisfaction. Career Development International, 19 (4), 426-446. http://dx.doi.org/10.1108/CDI-10-2013-0121

\section{Contact information}

Marcela-Sefora Nemteanu, Ph.D.

Babes-Bolyai University

Faculty of Economics and Business Administration

Department of Marketing

Romania

E-mail:sefora.sana@gmail.com

ORCID: 0000-0002-7831-9041

prof. Vasile Dinu, Ph.D.

Bucharest University of Economic Studies

Faculty of Business and Tourism

Department of Business

Romania

E-mail:dinu_cbz@yahoo.com

ORCID:0000-0003-3606-2548

prof. Dan-Cristian Dabija, Ph.D.

Babes-Bolyai University

Faculty of Economics and Business Administration

Department of Marketing

Romania

E-mail:dan.dabija@ubbcluj.ro

ORCID: 0000-0002-8265-175X 